Maria B. Kireeva ${ }^{1}$, Natalia L. Frolova ${ }^{2 *}$, Frank Winde ${ }^{3}$, Roald G. Dzhamalov ${ }^{4}$, Ekaterina P. Rets ${ }^{5}$, Elena S. Povalishnikova ${ }^{6}$, Olga M. Pahomova7

1 Faculty of Geography, Lomonosov Moscow State University, Moscow, Russia; Leninskie Gory, 1, 1199911, Tel. + 7-495-939-15-33, e-mail: kireeva_mb@mail.ru

2 Faculty of Geography, Lomonosov Moscow State University, Moscow, Russia; Leninskie Gory, 1, 1199911, Tel. + 7-495-939-10-01, e-mail:frolova_nl@mail.ru

* Corresponding author

3 School of Basic Sciences - Geography and Environmental Studies, North-West University, South Africa

${ }^{4}$ Water Problems Institute RAS, Moscow, Russia, Gubkin str., 3, 119333, tel. + 7 (499) 135-54-56, e-mail: dzhamal@aqua.laser.ru

${ }^{5}$ Water Problems Institute RAS, Moscow, Russia, Gubkin str., 3, 119333, tel. + 7 (499) 135-54-56, e-mail: retska@mail.ru

${ }^{6}$ Faculty of Geography, Lomonosov Moscow State University, Moscow, Russia; Leninskie Gory, 1, 1199911, Tel. + 7-495-939-15-33, e-mail: almond_a@mail.ru

7 Faculty of Geography, Lomonosov Moscow State University, Moscow, Russia; Leninskie Gory, 1, 1199911, Tel. + 7-495-939-10-01, e-mail: olpah@mail.ru

\title{
LOW FLOW ON THE RIVERS OF THE EUROPEAN PART OF RUSSIA AND ITS HAZARDS
}

\begin{abstract}
This paper reviews the changes in river flow of the European part of Russia during the low-flow period, characterizing groundwater flow feeding. River flow oscillations were analyzed for winter and summer periods. Statistical analyses of average low flow and the minimum monthly summer and winter discharges for 1946-1977 and 1978-2010 showed significant positive trends for all parameters of low-water period. The greatest increase is observed in the Middle Volga, where low flow has almost doubled.
\end{abstract}

The low flow discharges increased by up to 50-70 \% in the center of the European part of Russia and the Upper Don and its tributaries, ranging from 0 to $30 \%$ for the northern rivers. Despite the low flow increase, the lack of water in 2010 and 2014 caused economic damage. It is shown that the observed hydrological hazards occur as a result of snow melt draughts and water management instability.

KEY WORDS: low flow, lack of water, climate change, extreme hydrological events.

\section{INTRODUCTION}

Low flow period in the rivers of the European part of Russia occupies a large part of a year and determines the limits of water use in various sectors of economy. The increasing water needs for industry, agriculture, and population growth show more acute vulnerability of the society to the lack of water and draughts. That is why the questions related to low flow, flow distribution within the year, as well as the variability of these quantities are extremely relevant. Such studies are the basis for ecologically safe and economically effective use of water resources in Russia. The term "lack of water" can be interpreted as a period (on seasonal or long-term scale) of low river flow, having negative influence on economy. The lack of water is one of the dangerous hydrological 
phenomena. The number of extreme hydrometeorological events in Russia has nearly doubled from 1998 to 2013, according to the Federal Service for Hydrometeorology and Environmental Monitoring of Russia. In recent years, water shortages occurred in the basins of the Upper Volga and Oka (2010, 2014). Due to the low water levels in 2014 , navigation was virtually stopped, which led to the multimillion losses in river tourism.

The lowest water level in the rivers of the European part of Russia is commonly observed in winter and in summer-autumn seasons. It is associated with the formation of low flow period - the phase of water regime, during which the rivers are almost completely fed by groundwater. The parameters of low flow period (usually the mean flow of 3 months in summer/winter), the minimum monthly or 30-daily values, as well as the flow of the shorter periods from 1 to 30 days, are often used in calculation and forecast of minimum flow in Russia and abroad [SP 33-101-2003, 2004]. The last comprehensive study of the minimum flow in Russia took place in the early seventies of the last century when "Surface water resources of the USSR" was published. The overall assessment of the minimum river flow and approaches to its study were conducted in the works of Vladimirov A.M. [Vladimirov, 1970, 1976]. The comprehensive cartographic generalization of the parameters of minimum river flow of the European part of Russia has not been carried out over the past period. The changes in the minimum flow of some river basins are reviewed in the works of Bolgov M.V. and Philippova I.A. [Bolgov et al., 2005; Bolgov, Philippova, 2014; Philippova, 2014]. An increase in low flow of the European rivers of Russia was proved and the areas of the low flow synchronic oscillations were isolated. The research by the State Hydrological Institute [Shiklomanov et al., 2010; Water Resources of Russia, 2008] showed that the observed increase in the low flow is absolutely unique in the history of hydrometric observations in Russia.

Thus, there is an urgent need to create modern maps of the low flow parameters, analyze the long-term dynamics of these indicators, and compare it with emerging extreme hydrological events.

The purpose of this work is to study spatiotemporal dynamics of the minimum flow of the European rivers of Russia, generalize observation data of low flow, and analyze extraordinary low flow periods and their causes. This paper is the result of the investigations carried out by a group of scientists of the Institute of Water Problems (Russian Academy of Sciences) and Lomonosov Moscow State University in 20132014 [Dzhamalov et al., 2013, 2014].

\section{MATERIALS AND METHODS}

There are more than 1500 gauging stations located in the European part of Russia, some of them have the observation series starting from the XIX century. Three hundred forty eight catchments were chosen to analyze objectively the conditions of zonal flow formation of different regions of the European part of Russia. Preference was given to medium-size rivers with the catchment area 5 to 20 thousand $\mathrm{km}^{2}$ and characterized by natural flow. In some cases, the flow was estimated for the entire basin, as well as for its separate catchments. In this case, the parameters of flow were estimated as the difference of values between the outlet and the upstream cross section. The statistical parameters of the average low flow and the minimum monthly summer and winter flows were calculated for the selected representative catchments. At the same time, the low-water discharge was calculated as the averaged monthly discharges during the low flow period, which characterizes the groundwater feeding of rivers (Table 1).

Table 1. Terms of the lowest water level in the different river basins of the European part of Russia

\begin{tabular}{|l|c|}
\hline \multicolumn{1}{|c|}{ Basin } & Low flow period \\
\hline North Dvina, Pechora, Mezen & $\mathrm{XI-III}$ \\
Volga & $\mathrm{XII-I}$ \\
Oka & $\mathrm{XII-I}$ \\
Kama & $\mathrm{XII-I}$ \\
Don & $\mathrm{XII-II;VII-IX}$ \\
Ural & $\mathrm{XII-II}$ VIII-IX \\
\hline
\end{tabular}


The calculations were carried out for three periods of 1945-2010, 1945-1977, and 19782010. This division was made due to several factors. Firstly, in this case the flow series were divided into relatively equal parts. Secondly, during the Second World War most of the gauging stations did not work and there was a break in the observations. The choice of 1978 as a turning point is supported by studies of many authors [Water resources of Russia, 2008; Bolgov et al. 2014]. In particular, during the last 30 years, the climate change has become statistically significant. According to the analysis of residual curves for 60 gauging stations, the trend of the low flow increase has been observed since 1978. The variety of values of the "turning point year" for various rivers of the European Russia is 5-7 years and it is highly dependent on each specific parameter. However, the period of 1978-2010 was assumed as representative for the up-to-date trends in the minimum flow changes. Thus, the comparison of the average values of the minimum flow for the previous stable period and modern period with its usual dynamics was made. The statistical treatment of the series was performed with the help of the program STATISTICA. The water discharge series were tested by mathematical expectation (Student t-test) and variance (Fisher's test), as well as by the presence of directional trend (nonparametric Spearman test). To analyze the temporal dynamics of extreme hydrological events, the annual values of shortage and excess of water resources were calculated on monthly data for 20 major line gauging stations. At the same time the monthly water discharges of $10 \%$ and $90 \%$ probability were assumed as "threshold values". In addition, the ratio of the shortage or excess of water to the duration of this period was calculated for each river.

\section{RESULTS AND DISCUSSION}

\section{Low flow changes in different physical-geographical regions}

At the beginning of the XXI century, the low flow of the majority of the European rivers of Russia increased, on average, by 40-60\% compared with the values until the mid-1970s (Fig. 1). Positive significant trends of winter and summer low flow increases characterize the Upper and Low Volga basins. The maximum change in low flow is typical of the forest-steppe zone, and is not associated with the increase in snow cover, but with the decrease in spring flow and its transformation into groundwater. The low flow increase by $70-100 \%$ is observed in the same area, covering the basins of the Sura, Unzha, Vetluga, the lower reaches of the Kama and the Middle Volga. Southward on the flat part of the European part of Russia, the increase in low flow rapidly dissipates. And in the steppe regions of the Lower Volga and the Lower Don and the rivers of the KumaManycheskaya depression, it fades away or is even slightly reduced (up to $5 \%$, which is not statistically significant). The reduction in the low flow growth rate also takes place northward and is associated with the line of the biggest changes.

Currently, the average proportion of the groundwater flow of the North European Rivers of Russia is $~ 30-40 \%$ and it varies slightly for the rivers of the region. The significant increase in groundwater feeding, which in present-day conditions provides from 45 to $70 \%$ of the total annual flow, is observed in the Volga basin (except the Kama). This is mainly due to the winter lowwater increase. Roughly the same value of the groundwater flow proportion is typical of the upper reaches of the Don.

The flow increase in the low-water period is due to the growth of both winter and summer water discharges in the rivers of the southern slope of the European part of Russia (the middle and lower reaches of the Don, Kuban, Terek, etc.). This is due to the increased amounts of precipitation (Fig. 2). Changes in the average winter and summer low flows are relatively simultaneous, but with some time shift. The increase in the proportion of low flow in the annual runoff takes place with the decrease in average watershed altitude on the northern slopes of the Caucasus (the Terek, Kuban basins). The flattening-out of the 
꼼

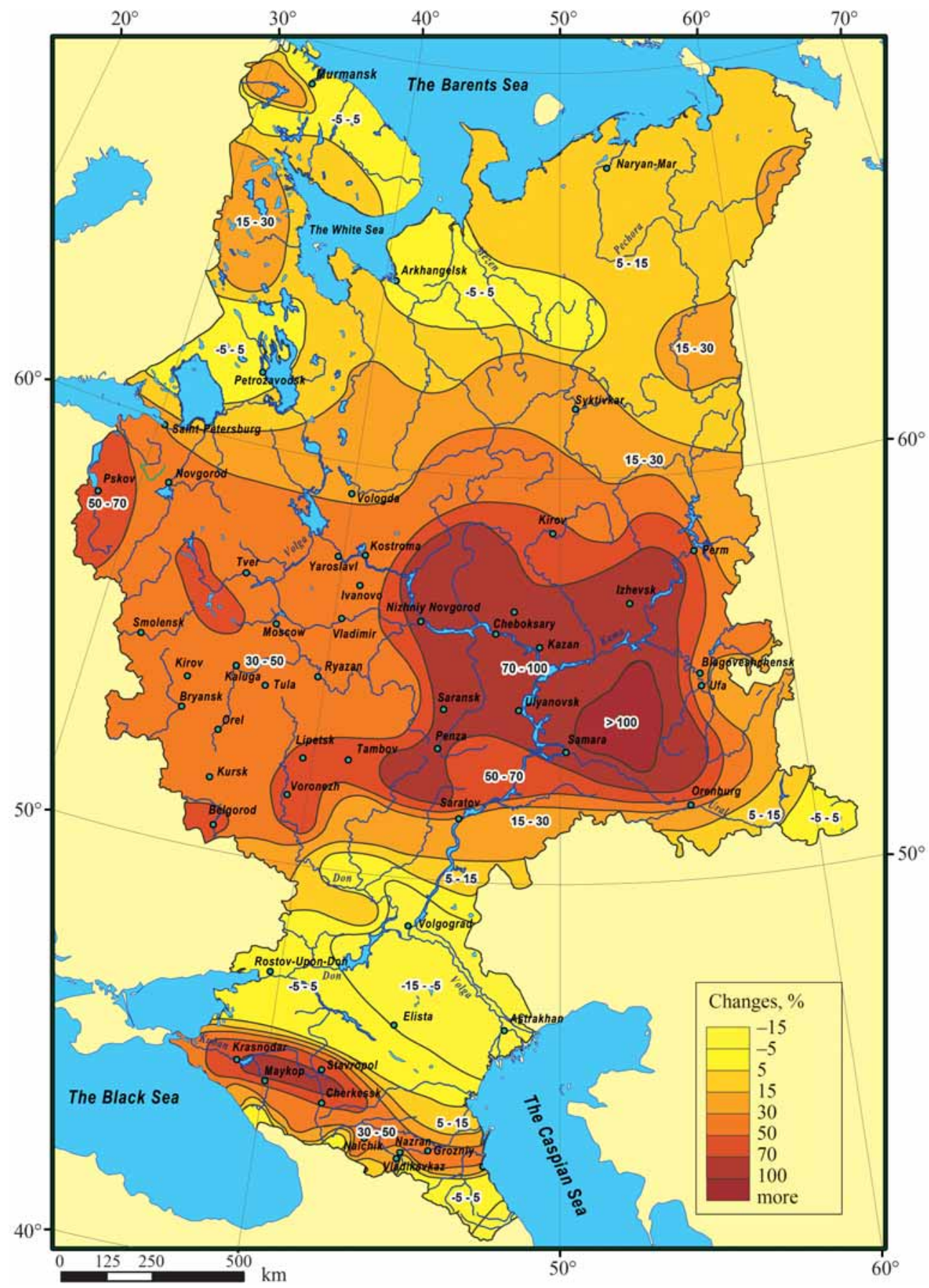

Fig. 1. Low flow changes of the European rivers of Russia 


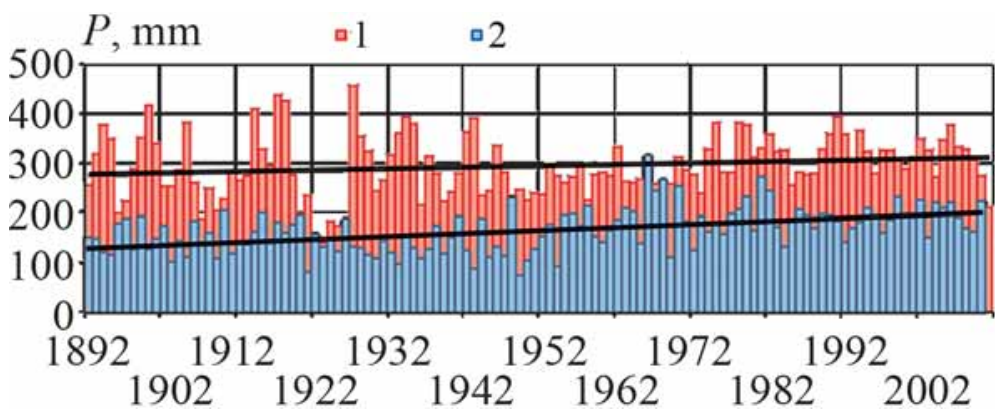

Fig. 2. Changes in precipitation during cold (XI-III) (1) and warm (IV-X) (2) periods for the Don River basin

low flow graph downstream the mountain river occurs under the increase in the area of low-altitude zone.

Groundwater flow in different climatic zones is formed by the so-called effective precipitation (seeping to the groundwater level). For the temperate zone of the European part of Russia it is usually the rainfall of winter-spring and autumn seasons. However, in the current climate conditions, the winter season is characterized by the increase in snow-rainfall flow which is formed from November to February-March due to frequent thaws. Close correlation (0.5-0.7) of groundwater flow of several rivers with the total November-April precipitations of the previous year was established. Compared with the precipitations of the current year, correlation has decreased to 0.3-0.4.

Average changes in the natural minimum resources for the summer and winter periods are $1-2 \mathrm{l} /\left(\mathrm{sec} \cdot \mathrm{km}^{2}\right)$. The maximum monthly yield (up to $2-3 \mathrm{l} /\left(\mathrm{sec} \cdot \mathrm{km}^{2}\right)$ ) is typical for the northern regions. In the lower reaches of the
Don and Volga rivers the minimum values decreased to $1 \mathrm{l} /\left(\mathrm{sec} \cdot \mathrm{km}^{2}\right)$ or less.

The minimum monthly flow in the northern rivers in the summer and winter periods varies from 15-25\% in the lower reaches up to $30-50 \%$ in the middle reaches (the Northern Dvina and Pechora). The most significant increase in the minimum monthly water discharge (50-70\% and more) occurs in the upper reaches of the Oka, the middle reaches of the Volga, and in the Ural basin. The increase in minimum flow is less significant (15\%), up to its decline to the south from this line (the mouth and the middle reaches of the Don, the Ciscaucasia). However, in the upper reaches of the Don and its local tributaries, the increase in the minimum monthly water discharges grows again by 50-70\% (Fig. 3). The similar increase in the minimum flow is observed in the basins of the northern slopes of the Caucasus Mountains.

The maps constructed to compare ratio the minimum monthly discharges growth over the

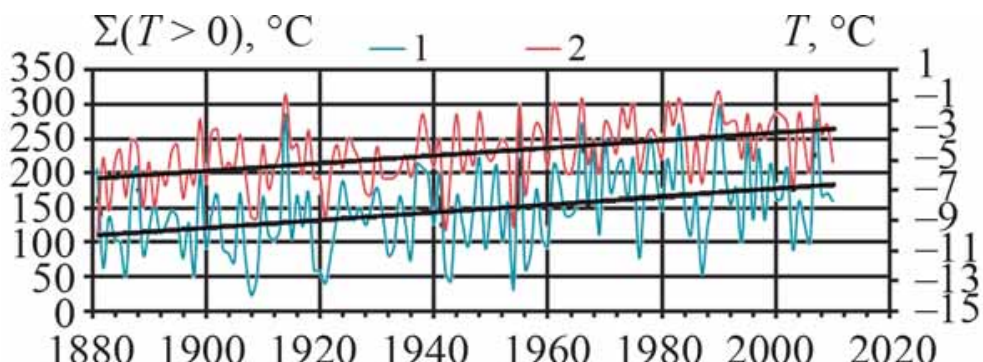

Fig. 3. Change in the above-zero (1) and average (2) temperatures during the cold (XI-III) period for the Don River basin 


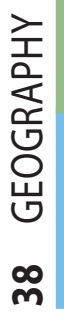
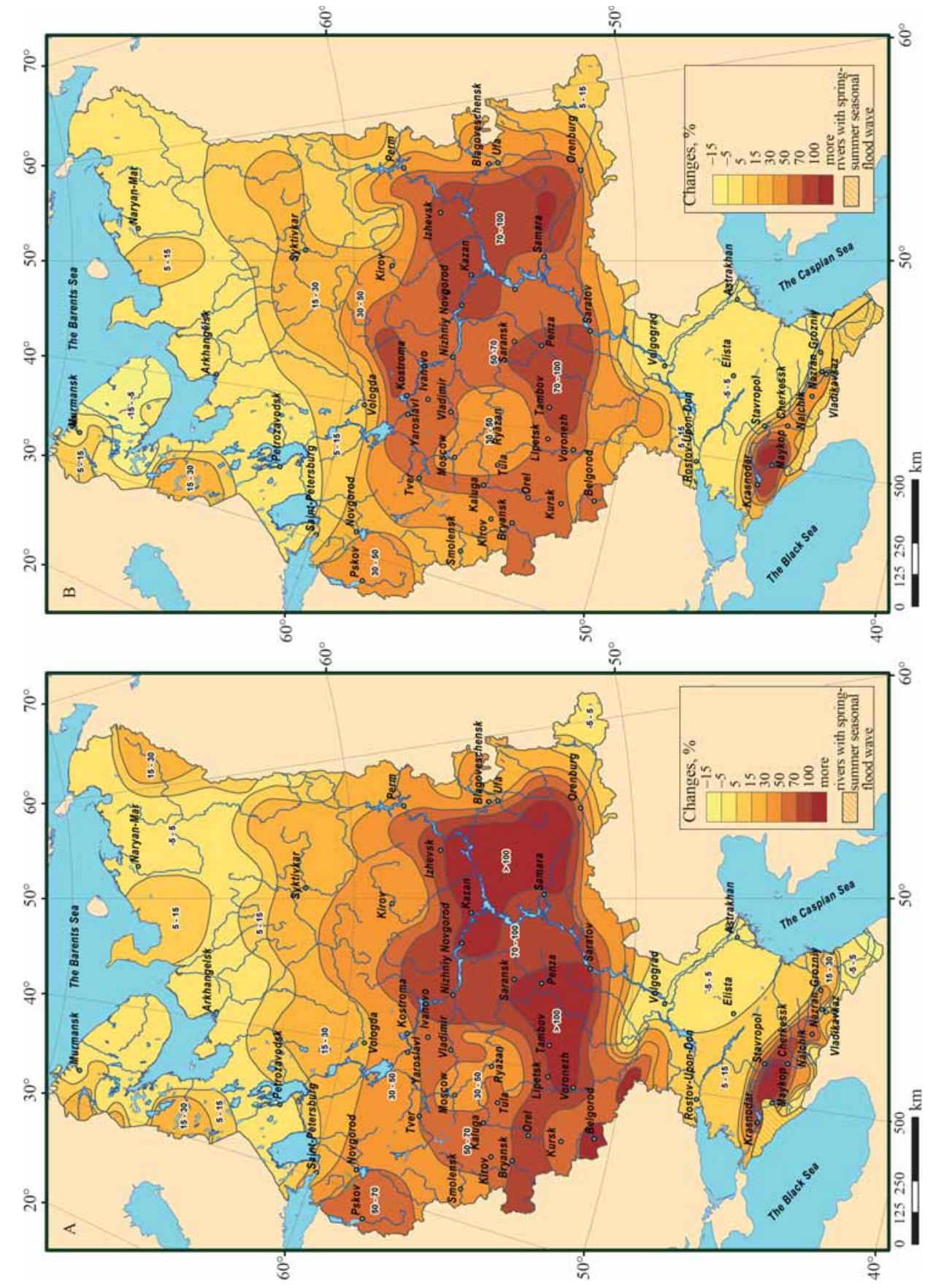

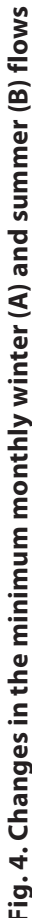


winter and summer periods (Fig. 4) show that the spatial variations of the minimum monthly winter and summer flows occur simultaneously. The growth of the minimum monthly winter discharge is by 20-30\% higher than the growth of the minimum monthly summer discharge almost everywhere. In the north and south of the European part of Russia the growth rate of summer and winter low flow is the same.

Intensive growth of winter minimum monthly discharges is associated with the number, duration, and depth of thaws. For example, for the twentieth century, the sum of positive temperatures during the winter period in the Don basin increased from 120 to 200 degrees. The average temperature of the winter period increased in the same way (see Fig. 3).

\section{Long-term variability of low flow parameters and its hazards}

The spatial analysis of low flow increase makes it possible to identify some specific regions with the similar low flow changes.

The entire Northern European part of Russia, in particular the Northern Dvina, Mezen, and Pechora basins, is a region with a statistically significant but relatively slight low flow growth. The period of the lowest water flow is observed here in winter - from December to March. The rest part of the year the wetness of the region is greater, frequent rain floods take place in summer. For the outlet gauging stations on major rivers the low flow changes are still statistically not significant (about 5-15\%) (Fig. 5 A). The relatively intensive

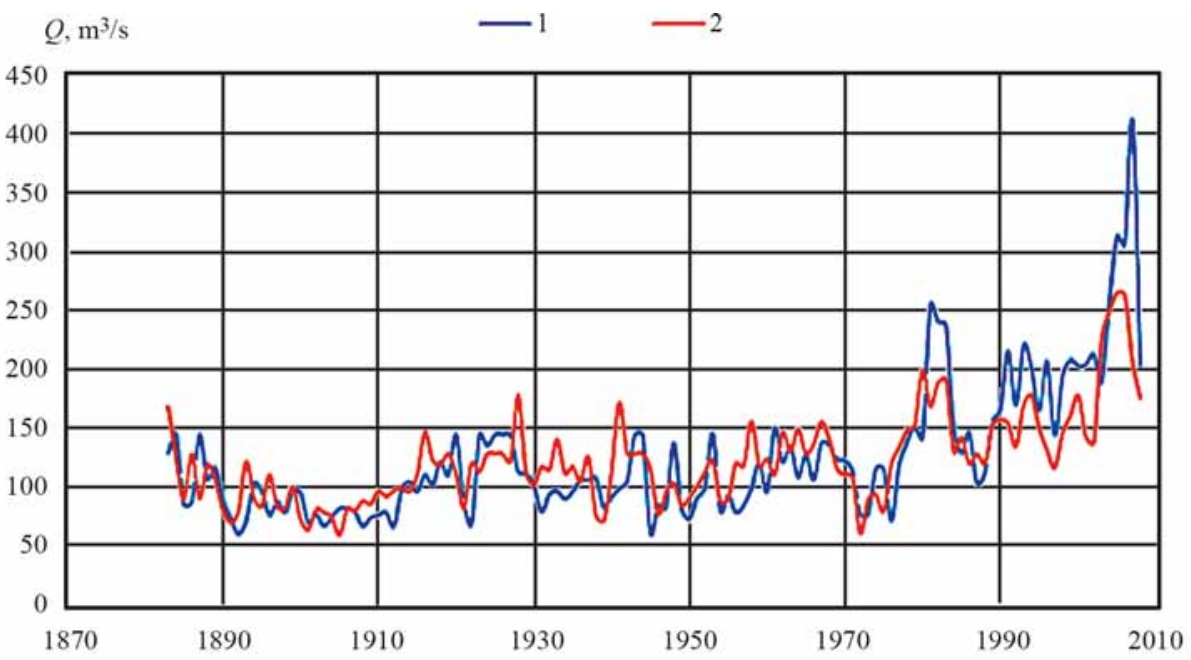

$\Delta V, \mathrm{~km}^{3}$

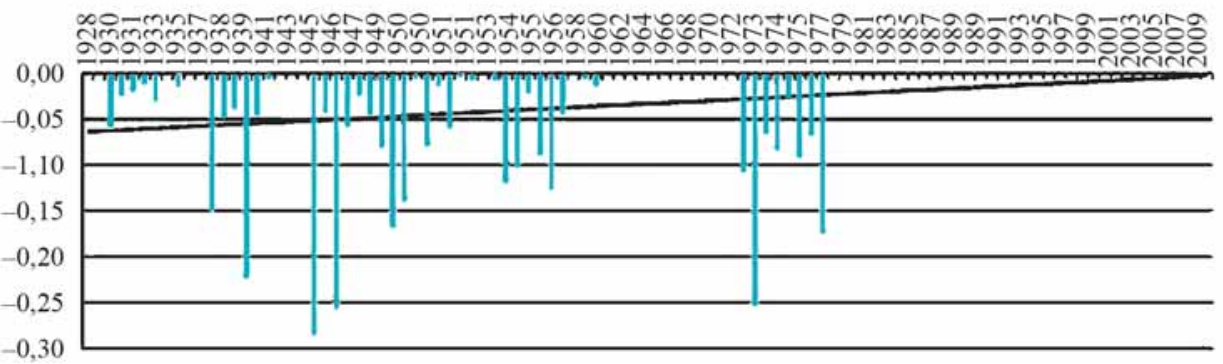

Fig. 5. A: Changes in the average low-flow (1) and limiting water discharges (2) in winter; B: volumes of water shortage under the threshold $Q_{0,9}$ (for the Northern Dvina River, Ust-Pinega) 
positive trends are typical for the southern parts of the basins - the upper reaches of the major rivers and their tributaries. For example, the low flow increase of the Yug River ranges from $30-50 \%$.

The northern rivers are characterized by smooth reduction of the volumes of water shortage. The deepest water shortages occurred here in 1938-1945, and 1965-1975 were extremely high-water years. Water shortage periods were also observed on these rivers in the 2000s, but, for example, most of the water shortages on the Northern Dvina were observed in the 1930-1940s. Thereafter a steady decline in the frequency of water shortages started. The duration of water shortages, on the contrary, increased from 1-2 to 3 months, and sometimes up to 4, and the volume - decreased. Big water shortage was observed in 2002 after a long break (Fig. 5 B).

The greater increase in the low flow is observed in the Central Russia, in the basin of the Upper Volga and Oka. The statistically significant increase in both of the average low flow and the minimum monthly water discharges for the winter and summer is observed for most of the rivers. The growth of low-water discharges ranges from 30 to $70 \%$ (Fig. 6 A). In addition, a pronounced recurrence is typical for low flow oscillations. A full cycle has the duration of about 30 years.

The extremely low water years were 1945, 1950, 1967-1969, and 1966, 1974, 1947-58 were high-water years in the Upper Volga

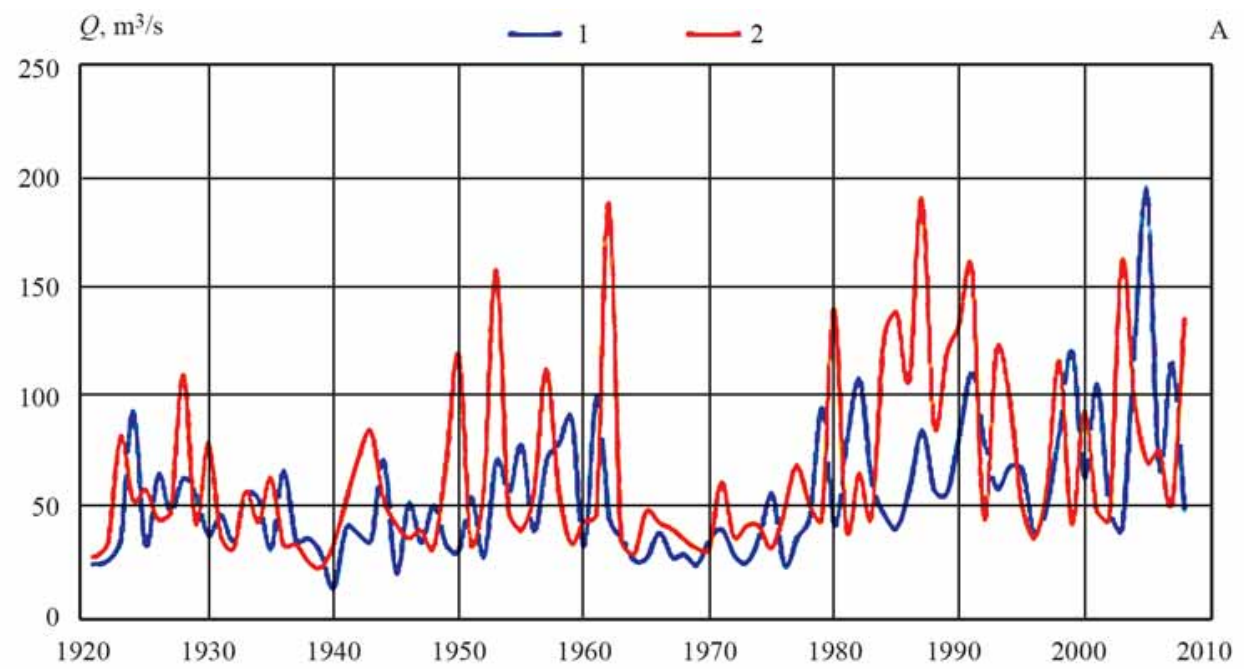

$\Delta V, \mathrm{~km}^{3}$

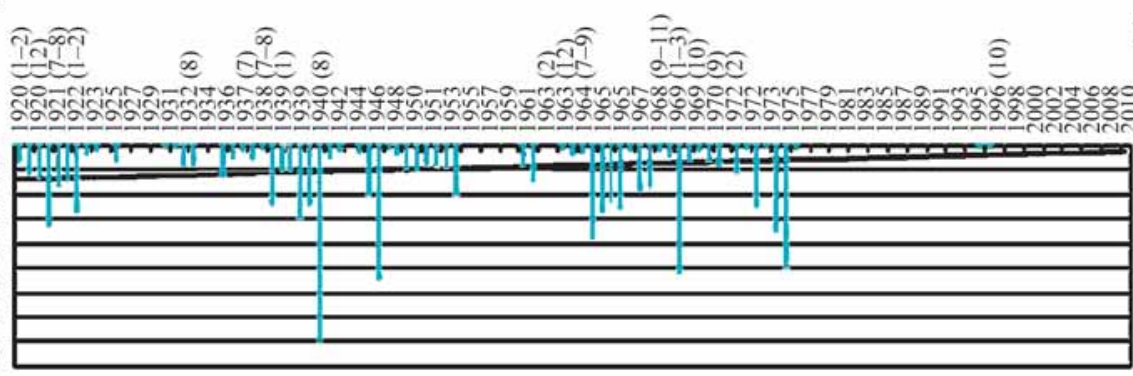

B

Fig. 6. Changes in the average low-flow water discharges (A) and volumes of water shortage under the threshold $Q_{0,9}$ (B) for the Volga River, Staritsa 


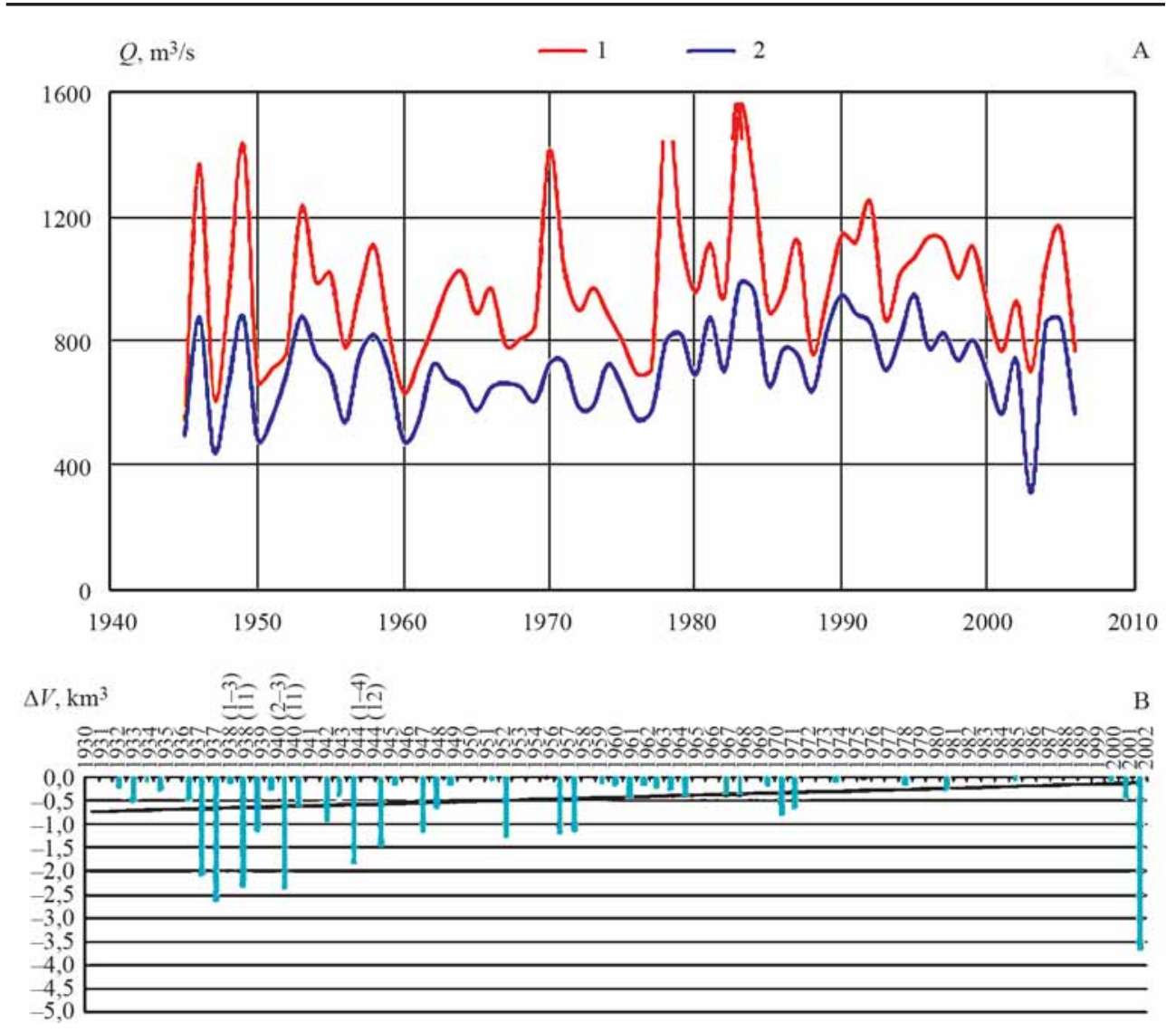

Fig. 7. A: changes in the monthly winter (1) and summer (2) water discharges; B: volumes of water shortage under the threshold $Q_{0,9}$ (for the Don River, village Kazanskaya)

basin. 1977 was the last year, when water shortage was observed (Fig. 6 B). The Volga tributaries have a somewhat different picture. The water shortages occurred mainly in 1937-1939, and the high-water period took place in 1958, 1970, 1979-1981 on the Oka, Ugra, Moksha, the last water shortages were observed here in 1973-1975 (except Moksha).

The trends similar to the North European part of Russia are observed in the eastern part of the region - in the Kama basin: there is a gradual decline of water shortage, the low-water period becomes shorter, and the flood period increases in volume. The greatest water shortages were observed here in the years of 1920-1940, and 1960-1970, and in the early 1990s were high-water years. Lack of water occurred here mainly in the years of 1920-1940. However, even in recent years (2006, 2008), as well as from 1976-1977, some water shortages also took place.

The most obvious changes were observed in the European south part of Russia, the Don and the Sura River basins. The greatest lack of water was recorded there in the late 1930 's - early 1940's, as well as in 1972. Since 1975-1977, water shortages, in general, have ceased and have been observed only partially in the Don River tributaries in extremely lowwater year of 2010 (Fig. 7).

Nevertheless, despite the increase in the low flow in 2010 and 2014, big lack of water was observed in summer. In 2010, it affected the basins of the Volga and Don and in 2014 mainly the Upper Volga. The cause of water shortages was low moisture reserve in the 


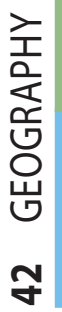

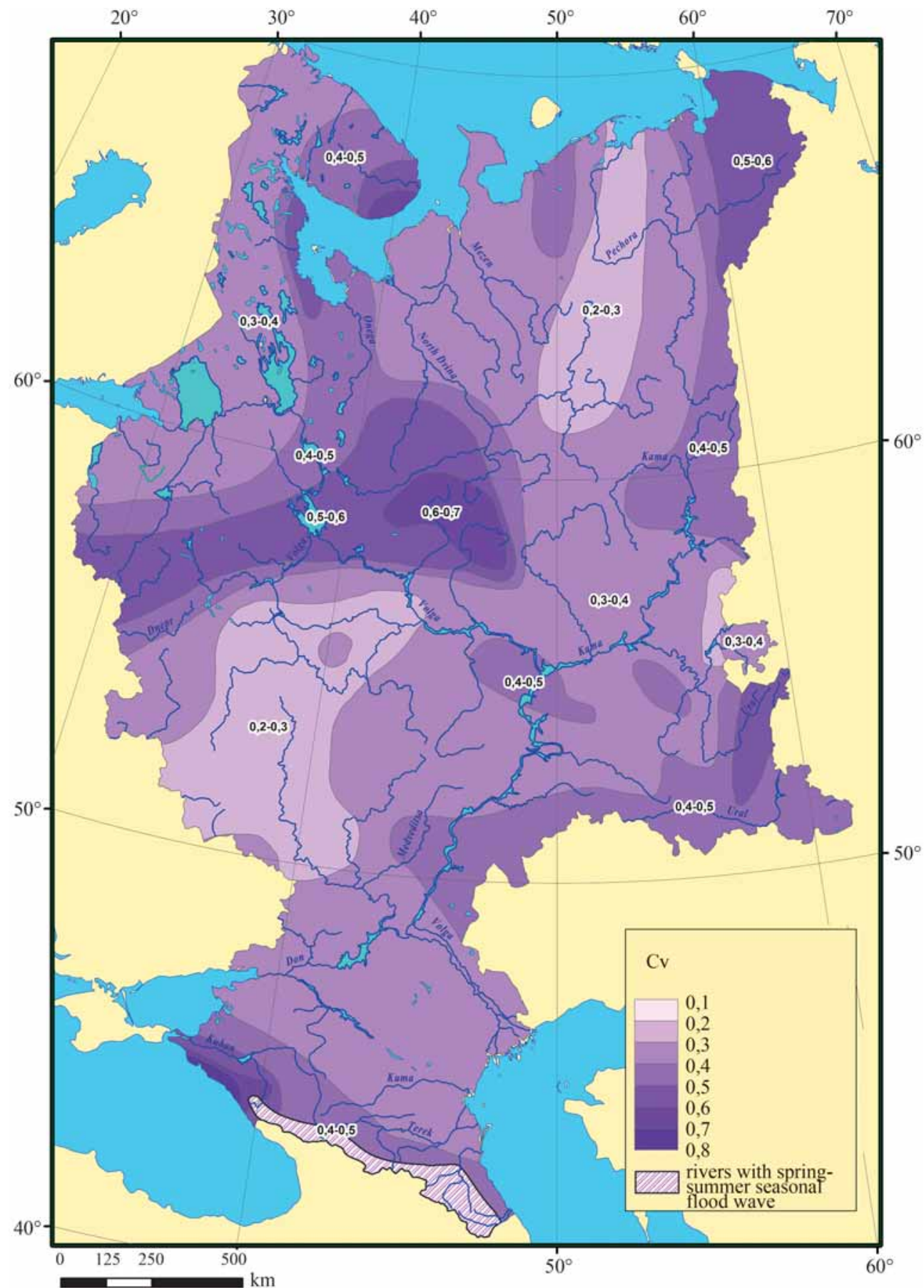

Fig. 8. Variation coefficient of the minimum summer flow in 1978-2010 
snow cover at the end of spring, associated with numerous thaws and radiation evaporation of snow, the lack of rains in the spring-summer period, and abnormally hot weather. According to [Van Loon et al, 2014], in such a case it is advisable to emphasize a special type of draught - the draught arising from anomalous melting of snow (snowmelt draught). Under such conditions, the highwater period on the rivers is not practically observed. Flood flattens, has many peaks, and does not compensate the drained water storage in the basin during winter.

The variability of the minimum flow in summer significantly increases due to the alternation of anomalous and typical winters. For example, the highest values of variation coefficient of the minimum summer flow throughout the European part of Russia, ranging from 0.5-0.7, occur in the Upper Volga basin (Fig. 8). High values of $C_{v}$ were also observed on the Kola Peninsula, in the basins of the Onega and Pechora Rivers, ranging from 0.4-0.5. Summer precipitation is strongly dependent on the North Atlantic cyclones and it is a highly variable process. High variability of the minimum summer flow is also observed in the basin of the Ural, which is subjected to spreading of the dry air masses from Central Asia.

\section{CONCLUSION}

The increase in water content in low-water has taken place due to the impact of climate change in the past 30 years on most of the European part of Russia, being unique throughout the history of hydrometric observations. These changes are different in various physical-geographic regions. The most intensive increase in the low flow occurs in the basin of the Middle Volga, where the low water discharges almost doubled (by $70 \%$ or more). The low flow increases rather intensely in the western rivers of the Upper Don and its tributaries - the Khoper and Medveditsa, in the basin of the Upper Volga (up to 50-70\%). Slightly less intensive growth (30-50\%) is observed in the large territory from latitude 52 to $60^{\circ} \mathrm{N}$. Almost the whole
Central Russia and the upper reaches of the Northern Dvina and Kama are situated in this zone. The smallest increase of the low flow is observed in the North European Russia in the basins of the Mezen, Pechora, middle and lower reaches of the Northern Dvina Rivers, as well as in the south - between the Lower Don and the Volga, the rivers of the KumaManycheskaya depression.

The low flow growth occurs due to increase of the summer and winter (by almost 1.5 times more intensely than the summer) water discharges. Frequent thaws, the overall increase in rainfall, both for summer and winter, the reduction of the depth of freezing and, in general, favorable conditions for infiltration, increased groundwater feeding are the main factors of the low flow growth. The number of water shortage periods is reduced. They become less harsh and more prolonged on most of the rivers of the European Russia. The average duration increased from 1-2 months to 3-4 months. In most of the rivers in Central Russia, the frequency of water shortages ceased at the end of the 1970s. Despite the overall reduction in water shortages, the lack of water in the Central part of Russia and the Volga and Don basins was observed in 2010 and 2014. Small water storage in the snow cover, spring radiation, frequent thaws, abnormally hot summers, and extremely low floods caused the lack of water.

All these factors in spring prevent river basins from water renewal; the draughts take place because of the lack of snowmelt water (snowmelt draught) [Van Loon et al, 2014]. Variation coefficient of the summer flow greatly increases in such conditions. Moreover, just for the Upper Volga it is maximal and reaches $0.5-0.7$.

\section{ACKNOWLEDGMENTS}

The study is financially supported by the Russian Foundation for Basic Research (Proj. № 16-35-60080), and the Russian Science Foundation (Grants NNo. 14-17-00155 and 14-17-00700) for calculations and data. 


\section{REFERENCES}

1. Bolgov M.V., Korobkina E.A., Trubetskova M.D., Filimonov M.K., Filippova I.A. (2014) Sovremennie izmenenia minimalnogo stoka na rekakh basseina Volgi (Recent changes in the minimum flow of Volga basin rivers). Meteorology and Hydrology. № 3. - p. 75-85 (in Russian).

2. Bolgov M.V., Michon V.M., Sentsova N.I. (2005) Sovremennie problemy otsenki vodnikh resursov i vodoobespechenia (Modern problems of water resources assessment and water supply). Moscow: Nauka. 318 p. (in Russian).

3. Dzhamalov R.G., Frolova N.L., Bugrov A.A., Grigorjev V.Y., Igonina M.I., Kireeva M.B., Kritchevets G.N., Rets E.P., Safronova T.I., Telegina A.A.,Telegina E.A., Fathi M.O., (2014) Atlas vozobnovlyaemikh vodnikh resursov Evropejskoy chasti Rossii (Atlas of renewable water resources of the European part of Russia). M.: «Rovix» Ltd., ISBN 978-5-4347-0033-7. 96 p. (in Russian).

4. Dzhamalov R.G., Frolova N.L., Kireeva M.B. (2013) Current changes in river water regime in the Don River Basin. Water Resources Maik Nauka/Interperiodica Publishing (Russian Federation). Vol. 40. № 6. p. 573-584.

5. Dzhamalov R.G., Frolova N.L., Kireeva M.B., Rets E.P. (2014) Present-day surface and subsurface water resources of European Russia: conditions, use and forecast. IAHS Publ., № 363. p. 215-220.

6. Shiklomanov I.A, Georgievskij V.Y., Babkin V.I., Balonishnikova Z.A. (2010) Problemi izuchenia formirovania i otsenki izmeneniy vodnikh resursov I vodoobespechennosti Rossii (Problems of studying the formation and evaluation of changes in water resources and water availability in Russia). Meteorology and Hydrology. № 1. p. 23-32 (in Russian).

7. Van Loon A.F., S.W. Ploum, J. Parajka, A.K. Fleig, E. Garnier, G. Laaha, and H.A. J. Van Lanen. (2014) Hydrological drought typology: temperature-related drought types and associated societal impacts. Hydrology and Earth System Sciences.

8. Vladimirov A.M. (1970) Minimalniy stok rek SSSR (Low flow on the rivers of the USSR). L.: Gidrometeoizdat. 214 p. (in Russian).

9. Vladimirov A.M. (1976) Stok rek v malovodiy period goda (River flow during the lowwater season). L.: Gidrometeoizdat. 295 p. (in Russian). 


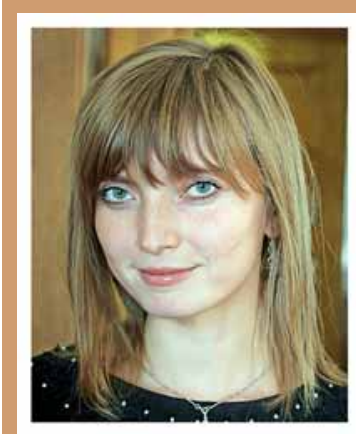

Maria B. Kireeva received her PhD from the Lomonosov Moscow State University in 2013. Her research is associated with low flow, intra-annual redistribution of river runoff, and seasonal and occasional flood dynamics. Main publications: The role of seasonal and occasional floods in the origin of extreme hydrological events (2015, with co-authors); Present-day surface and subsurface water resources of European Russia: conditions, use and forecast (2014, with co-authors); Up-to-date climate forced seasonal flood changes (the case study for European part of Russia) (2014, with co-authors).

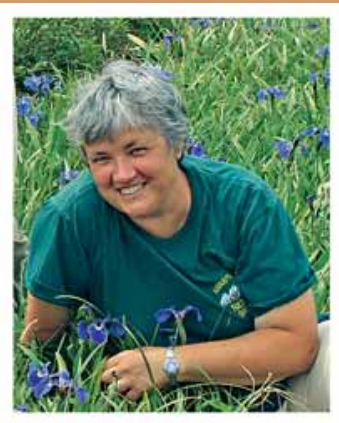

Natalia L. Frolova, Professor of Hydrology at the Lomonosov Moscow State University, where she received her Ph. D. and D. Sc. (2013) in Hydrology. She teaches hydrology undergraduate and graduate level courses ("Hydrology", "Hydrology of Rivers", and "Hydrological Forecasts") in Russia and Kazakhstan. Her research work is associated with the dangerous hydrological processes and water resources with particular focus on the impact of climate change. Main publications: Monitoring of hydrological processes and increase of safety of water use (2011, with coauthors); The Analysis of Dangerous Hydrological Processes for the Terek River Basin (2009, with Alexeevskiy N.I.); Distribution and Use of Present Day Water Resources in European Russia (2015, with co-authors).

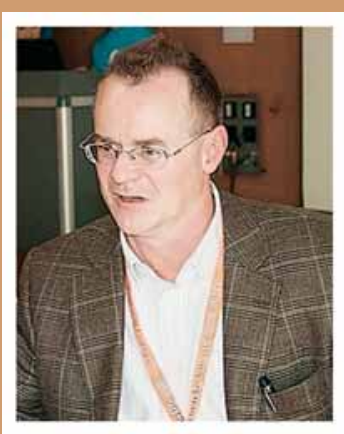

Frank Winde graduated in 1993 as Diplom Geographer (MSc). In 2003 he completed his Habilitation at the University of Jena (Germany). In 2004 he was appointed as an associate professor at the North-West University. Since February 2012 he is full professor and heads the Subject Group Geography and Environmental Studies at the Vaal Campus of the NWU. He conducted over 20 research projects on 3 different continents, and also served as scientific advisor to various Governmental departments in South Africa, municipalities in Germany and South Africa as well as to the mining industry and other parts of the private sector. His research was presented at well over 50 international conferences and in more than 70 publications including 30 full-length research papers in scientific journals, 20 chapters in books, 2 full monographs and 18 papers in published proceedings of international conferences as well as numerous research reports. 


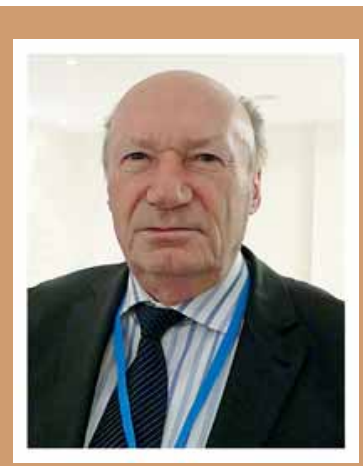

Roald G. Dzhamalov, D. Sc. in Geology and Mineralogy, is the Chief of Laboratory at the Water Problems Institute of RAS, Corresponding Member of the RANS, Member of the Hydrology Institute in USA, and Savarenskiy Prize winner of the RAS. His research is associated with resources and quality of underground flow. Main publications: Elsevier's Dictionary of Geoenvironment and Natural Disasters (1999, with Safronov Y.V.); World Map of Hydrogeological Conditions and Groundwater Flow, scale 1:10 000000 (1999, with Zektser I.S.); Engineering geology with geocryology (2003).

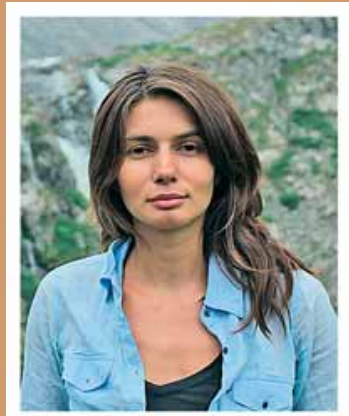

Ekaterina Rets received her Ph. D. from the Lomonosov Moscow State University in 2013. She is now Associate Researcher at the Water Problems Institute, RAS. Her main research interests are water resources, mountain hydrology, modelling of hydrological processes, and programming. Main publications: The role of seasonal and occasional floods in the origin of extreme hydrological events (2015, with co-authors); Present-day surface and subsurface water resources of European Russia: conditions, use and forecast (2014, with co-authors); Up-to-date climate forced seasonal flood changes (the case study for European part of Russia) (2014, with co-authors).

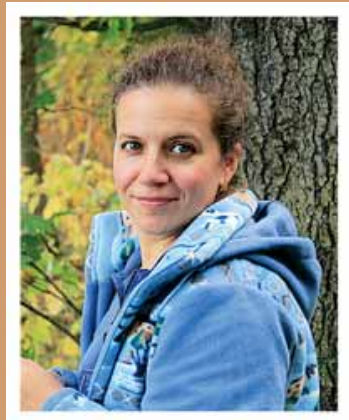

Elena S. Povalishnikova is Senior Scientist at the Department of Hydrology, Faculty of Geohraphy, Lomonosov Moscow State University (MSU). She received her Ph. D. in geography from MSU in 1995. The focus of her research is associated with rivers, hydrological regime, water resources, water management, and remote sensing. Main publications: Use of the remote sensing in monitoring of the reserved water objects (2013, with co-authors); Natural river flow regulation in the Volga River Basin under the changing climate (2013, with co-authors); Nature management peculiarities and hydroecological condition of the Borovno-Razliv lake-river system (national park "Valdayskiy") (2012, with co-authors). 


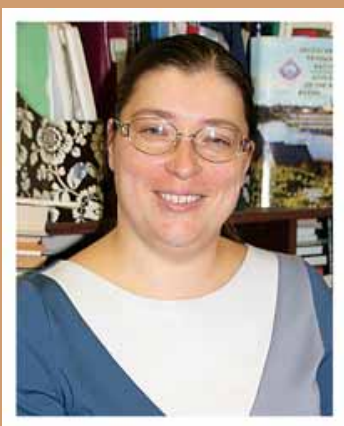

Olga M. Pahomova is currently Research Associate at the Lomonosov Moscow State University, Faculty of Geography, Department of Land Hydrology. She received the Ph. D. in hydrology, water resources, and hydrochemistry in 2001. Her primary research interests are in the fields of geography, water resources, channel processes, and hydrology. Main publications: Estimation of negative influence of the low water level in 2010 on the social-economic complex of the Russian Federation (2013, with co-authors); The quality of water in the Ural River catchment area as one of the systemic problems of transboundary water management between Russia and Kazahstan (2015, with co-authors); Lateral channel deformations and their relation to the order of river (2002). 